\title{
EFFECT OF SELENIUM AND VITAMIN E INJECTION ON DIGESTIBILITY COEFFICIENTS AND NUTRITIVE VALUE OF BALADI DOE GOATS IN SOUTHERN SINAI.
}

\author{
Ahlam R. Abdou \\ Animal and Poultry Nutrition Department, Desert Research Center, Mataria, Cairo, P.O. Box11753, \\ Egypt \\ E-mail:- ahlamramadan61@yahoo.com
}

SUMMARY

$\mathrm{T}$ The present study aimed to investigate the effect of different injection levels of selenium plus vitamin $\mathrm{E}$ on goat performance, intake, digestibility, nutritive value and body weight of kids. Forty Baladi doe goats $2-3$ year old and $(20.47 \pm 1.82 \mathrm{~kg})$ average live body weight were randomly divided into four groups (10 does each). The first group was a control group, does of $2^{\text {nd }}, 3^{\text {rd }}$ and $4^{\text {th }}$ groups received two injections of selenium and Vit. E; at early and late periods of gestation as follows, $0.125 \mathrm{mg} \mathrm{Se}+$ $1.7 \mathrm{IU}$ Vit. E/kg BW for $2^{\text {nd }}$ group (T1), $0.250 \mathrm{mg} \mathrm{Se}+3.4 \mathrm{IU}$ Vit. E $/ \mathrm{kg} \mathrm{BW}$ for $3^{\text {rd }}$ group (T2) and $0.310 \mathrm{mg}$ $\mathrm{Se}+4.2 \mathrm{IU}$ Vit. E/kg BW for $4^{\text {th }}$ group (T3). Digestibility trials were carried out after each injection. Does were fed a basal ration of concentrate feed mixture and the roughage portion of the diet was Berseem hay. Body weight of dams and kids were recorded. Results revealed that, the injection of both Se and Vit. E did not show any significant effects on TDMI and CPI of treated groups at either period of pregnancy. Control group showed higher $(\mathrm{P}<0.05) \quad \mathrm{CPD} \%$ than treatments. Whereas, EED\% was increased with Se supplementation. Supplementation of Se and Vit. E increased TDN\% at late period and decreased NB at early and late pregnancy compared to control. Supplementation increased weight gain during pregnancy. Control and $\mathrm{T} 2$ recorded higher $(\mathrm{P}<0.05)$ average weaning weight, and daily gain than $\mathrm{T} 3$ and $\mathrm{T} 1$ groups. It could be concluded that lower level (0.125 mg Se plus $1.7 \mathrm{IU}$ Vit. E/ $\mathrm{kg} / \mathrm{kg} \mathrm{BW})$ injection during early and late gestation improved nutrients digestibility, nutritive values, nitrogen utilization

Keywords: Goats, selenium, vitamin E, digestibility coefficients, growth.

\section{INTRODUCTION}

Many regions in the world are poor in soil selenium (Se) content which in turn, resulted in inadequate selenium levels in forages and crops. Furthermore, under south Sinai conditions of high salinity of water irrigation, growing plants aren't capable to maintain their needs of selenium from the poor soil (Mikkelsen et al., 1988 and Sadek, 1995). Subsequently, selenium supplementation is used to enhance dietary utilization (Ceballos et al., 2009).

Vitamin E is very important for the development of the immune system of young animals and this is an important factor in improving performance of lambs receiving high levels of vitamin $\mathrm{E}$ supplementation (Kolb and Seehawer, 1998). Moreover, vitamin E inhibits the conversion of existing lipid peroxides to the much more reactive and destructive peroxide radials (Chris et al., 2003). After reviewing vitamin E studies, in human and animals, Kelleher (1991) concluded that vitamin E requirements were based on lymphocyte proliferation or, more generally, on immune function than the indicators to muscle degeneration. The biological effects of vitamin $\mathrm{E}$ are predominantly seen in the prevention of resumption of fetuses, testicular degeneration, muscle dystrophy, anemia and encephalomalacia, the classical signs of vitamin E deficiency in animals (Salama et al., 2015). A major contributor to non- enzymatic protection against lipid peroxidation is vitamin E, a known free radical scavenger (Rikans et al., 1991). Both selenium and vitamin E are antioxidants because they both protect the membranes from oxidative damage (Gutteridge and Halliwell, 1994). Selenium (Se) plays important roles in several metabolic processes including antioxidant defense systems, thyroid hormone metabolism and immune function (Brown and Arthur, 2001). Selenium is an essential component of glutathione peroxidase, an enzyme involved in detoxification of hydrogen peroxide and lipid hydro-peroxides. Selenium has also been shown to improve immune responses (Sheffy, 1979) as it is required for the development and expression of non- specific humeral and cell mediated immune responses. Selenium 
deficiency plays a role in numerous economically important livestock disease, problems that include impaired fertility, abortion, retained placenta and neonatal weakness (Mc Dowell et al., 1996). Earlier, National Research Council NRC (1985) recommended a dietary level of (0.1 to $0.2 \mathrm{ppm})$ of Se for sheep. Selenium is known to be required (0.05-0.1 mg Se/kg diet) for animal health (Mayland et al., 1989). Marai et al (2009) reported that dietary selenium supplementation improved reproductive performance in sheep.

Supplementation of Se improves lambs' growth rate and reproductive performance in ewes (Ibrahim 2017). Selenium has high importance to human health due to its role in immune system activation and reduction of the risk of cardiovascular disease and cancer. Therefore, the objective of this experiment was to determine the effect of different levels of Se/vitamin E injections on the productivity of pregnant of goats in Southern Sinai.

\section{MATERIALS AND METHODS}

The present study was carried out at Ras Suder Experimental Station, Desert Research Center to investigate the effect of injections of Se+ Vit E at different levels on the productivity of Baladi doe goats under the conditions of South Sinai

\section{Animals, experimental design and feeding}

Forty Baladi doe goats 2-3 year old and $(20.47 \pm 1.82 \mathrm{~kg})$ average live body weight were randomly divided after mating into four groups (10 of each).

The first group was served as control; the other experimental groups (T1, T2 and T3) received the following intramuscular injection according to Ramirez-Bribiesca et al., (2005)

The first group was a control group.

The second group (T1): $0.125 \mathrm{mg} \mathrm{Se}+1.7 \mathrm{IU}$ Vit. E/kg body weight.

The third group (T2): $0.250 \mathrm{mg} \mathrm{Se}+3.4 \mathrm{IU}$ Vit. E/kg body weight.

The four group (T3): $0.310 \mathrm{mg} \mathrm{Se}+4.2 \mathrm{IU}$ Vit. E/kg body weight.

The experimental groups (1,2 and 3) were injected two times; the first injection was done after 60 days of pregnancy (early pregnancy), while the second injection was done after 108 days of pregnancy (late pregnancy). Animal evaluations were carried out 20 days after injections.

Animals were fed a basal ration of concentrate feed mixture (CFM) consisted of $43 \%$ yellow corn, $22 \%$ cotton seed meal, $20 \%$ wheat bran, $12 \%$ rice bran $1.5 \%$ limestone, $1 \%$ sodium chloride and $0.5 \%$ mineral mixture). Roughage portion of the diet was Berseem hay. Rations were formulated on basis concentrate/roughage ratio of 60:40 and 70:30 in early and late pregnancy, respectively. Concentrate feeds were calculated and formulated depending on the physiological status of does according to Kearl (1982).

The experimental period covers the whole pregnancy and weaning ( 4 months) periods. Kids were assigned to four groups to study the effect of injection on kids' growth performance past birth up to 16 weeks. Same treatments were applied to kids as dams. Chemical composition of the experimental diet was shown in Table (1).

\section{Digestibility trials}

Digestibility trials were carried out after 20 days of each injection. Three goats from each group were selected at random and subjected to the digestibility trials. Each trial lasted for 14 days as preliminary period followed by a 5-day collection period. The concentrate feed mixture (CFM) was offered daily at 8.00 a.m. and Berseem hay at 12.00 p.m. Daily amounts of feed intake, feces and urine output were recorded during the collection period. Collected feces samples were weighed and mixed thoroughly by hand and sub samples representing $10 \%$ of daily fecal production from each doe were weighed. Representative samples of each daily collection of diets and feces were pre-dried in drying oven at 60-70 ${ }^{0} \mathrm{C}$ for $48 \mathrm{hrs}$. and then ground to pass through a one $\mathrm{mm}$ mill screen. Chemical composition and digestibility coefficients of DM, CP, EE, CF and NFE were determined according to AOAC (1997). Digestible energy (DE M cal/kg DM) was calculated according to NRC (1985). 


\section{Body weight}

Does were weighed at the beginning of the experiment and, then, biweekly basis before and after lambing. This process took place in the morning just before offering feed and water. Throughout the experimental period, body weight changes were recorded for each animal during early and late pregnancy. After kidding body weights of does were recorded biweekly. Weights of kids were recorded from birth up to 16 weeks of age at two week intervals.

Statistical analysis was carried out using General Linear Model (GLM) procedures by SAS (2004). Fixed models, one, two and three-way analysis of variance, were used. Firstly, one way analysis was used to body weight of goats, body weight of kids, and milk yield, according to the following model:

$$
\mathrm{y}_{\mathrm{ij}}=\mu+\mathrm{T}_{\mathrm{i}}+\mathrm{e}_{\mathrm{ij}}
$$

Where $\mathrm{y}^{\mathrm{ij}}$ : is the $\mathrm{j}^{\text {th }}$ sample of the $\mathrm{i}^{\text {th }}$ substitution level, $\boldsymbol{\mu}$ : overall mean, Ti: the fixed effect of the $\mathrm{i}^{\text {th }}$ substitution level ( $\mathrm{i}=1$ to 4 ) and eij: experiment error assumed to be normally and independently distributed.

Secondly, two- way analysis of variance was used to examine the effect of substitution levels, and the interactions between them, according to the following model:

$$
\mathrm{Y}_{\mathrm{ijk}}=\mu+\mathrm{T}_{\mathrm{i}}+\mathrm{Z}_{\mathrm{j}}+\mathrm{TZ}_{\mathrm{ij}}+\mathrm{e}_{\mathrm{ijk}}
$$

Where: $Y_{i j k}=$ observations value of the $k^{\text {th }}$ animal, $T i=$ effect of $i^{\text {th }}$ period (i: $\left.1-2\right), Z_{j}=$ effect of $j^{\text {th }}$ treatment $(\mathrm{j}: 1-4), \mathrm{TZ}_{\mathrm{ij}}=$ the interaction between groups. Significant differences among treatment means were tested using Duncan multiple range test (Duncan, 1955).

\section{RESULTS AND DISCUSSION}

\section{Feed intake}

Feed intake (FI), total dry matter intake (TDMI) and crude protein intakes (CPI, g/ Kg BW) as well as digestible energy (DE) of the experimental does are shown in Table (2). The obtained results demonstrated that TDMI at early period of pregnancy $(22.62 \mathrm{~g} / \mathrm{Kg} \mathrm{BW})$ was significantly lower $(\mathrm{P}<0.05)$ than that of the late pregnancy $(28.92 \mathrm{~g} / \mathrm{Kg} \mathrm{BW})$ (Table 2). Also crude protein intake (CPI, g/Kg BW) at early period of pregnancy $(3.64 \mathrm{~g} / \mathrm{Kg} \mathrm{BW})$ was significantly lower $(\mathrm{P}<0.01)$ than that of the late pregnancy $(4.71 \mathrm{~g} / \mathrm{Kg} \mathrm{BW})$. On the other hand, injection of both Se and Vit E did not affect significantly either the TDMI or CPI at both periods of pregnancy (Table 2).

Intake of digestible energy (DE) differed significantly $(\mathrm{P}<0.001)$ between the two periods of pregnancy being 625.62 and $836.92 \mathrm{Mcal} / \mathrm{Kg}$ BW at early and late period of pregnancy, respectively. On the other hand, T2 $(0.250 \mathrm{mg}$ Se +3.4 IU Vit E/kg Body weight $)$ showed higher $(\mathrm{P}<0.05)$ values of total digestible energy intake (TDEI) in both periods for early and late periods of pregnancy than those of T1 and T3. Control group did not differ from other treatments with regard to DE intake (Table 2). These results are in agreement with the findings of Neeraj et al. (2008) where supplementation of selenium at 0.15 and $0.30 \mathrm{ppm}$ levels had no effect on palatability and DMI pattern of the animals. Vinu et al. (2012) reported that TDMI of calves was not significantly affected by the supplementation of $0.3 \mathrm{ppm}$ organic selenium as compared with control. Juniper et al. (2008) observed no effect of different dietary levels of selenium yeast $(0.2$ to $6.74 \mathrm{ppm})$ on the dry matter intake of male buffalo calves. Tufarelli and Laudadio (2011) registered no significant differences $(\mathrm{P}<0.05)$ in dry matter intake of dairy goats when Se was supplement in concentrate $(0.20 \mathrm{mg} /$ head per day of Na-selenite and $20 \mathrm{mg} /$ day per head of Vit. E).

Serra et al. (1994) reported that supplementation of $0.2 \mathrm{ppm}$ Se to the basal diet (31.74 ppb Se) did not affect the DM consumption of sheep.

\section{Digestion coefficients}

Data of Table (3) clearly showed that as the level of Se and Vit. E increased the digestibility's of DM, $\mathrm{OM}, \mathrm{CP}$ and NFE were significantly decreased at both early and late pregnancy.

Injection of Se and Vit. E showed a significant decreasing trend of DMD as the level of Se increased at both early and late pregnancy (Table 3). Early pregnancy control group of animals had the highest significant DMD (74.48\%), T1, T2 and T3 showed lower significant DMD values $(71.59 \%, 68.87 \%$ and $67.22 \%$, respectively). During the late period of pregnancy, the same trend of DMD was found as that of 
early period of pregnancy; yet the values were $76.13 \%, 75.60 \%, 73.46 \%$ and $70.37 \%$ for control, T1, T2 and T3, respectively. The overall mean of dry matter digestibility (DMD \%) at the early pregnancy period was $70.54 \%$ compared to $73.89 \%$ for the late pregnancy period with insignificant manner.

At early pregnancy, control group showed the highest $(\mathrm{P}<0.05) \mathrm{CPD}$ value $(76.74 \%)$. while, at late pregnancy, T1 had the highest CPD (\%) value. Among treatments, the injection of Se and Vit E at the level of $(0.310 \mathrm{mg} \mathrm{Se}+4.2 \mathrm{IU}$ Vit. E/ kg Body weight, T3) at both periods of pregnancy showed the lowest significant $(\mathrm{P}<0.05) \mathrm{CPD}(70.12$ and $72.03 \%)$ for early and late pregnancy periods, respectively. The overall mean of crude protein digestibility (CPD, \%) at early period of pregnancy was $72.78 \%$ and that of late period was $73.89 \%$ with insignificant manner (Table 3).

Among treatments, EED (\%) was increased insignificantly with the Se + Vit. E supplementation at early and late pregnancy periods. Ether extract digestibility (EED, \%) of goats at the early pregnancy period was higher $(\mathrm{P}<0.01)(77.87 \%)$ compared to $(71.54 \%)$ for the late pregnancy period. Digestibility of CF was significantly decreased with increased Se plus vitamin E in late pregnancy (Table 3).

These results are in agreement with those found by Kholif and Kholif (2008) who found that digestibility of OM, EE, CF and NFE were significantly increased with buffaloes fed low amount of selenium enriched yeast followed by high amount of selenium enriched yeast and then control. Furthermore, Nicholson et al. (1991) observed that upon the supplementation of 1ppm of Se, there was no effect on the digestibility of OM, CP and NDF in calves. Neeraj et al. (2008) noticed that the supplementation of 0.15 and $0.3 \mathrm{ppm}$ Se (through sodium selenite) had no effect on digestibility of these nutrients in lambs. Zohreh et al. (2018) found that, apart from crude fat, no significant differences for all other apparent nutrient digestibility, as well as total digestible nutrients $(\mathrm{P}<0.05)$. Shi et al. (2011) attributed the improvements in total dry mater, crude protein, and either extract digestibility's to the increase in Se level from 0.15 to $0.45 \mathrm{mg} \mathrm{Se} / \mathrm{Kg} \mathrm{DM}$ in male goats.

Kassab and Mohammed (2014) where nutrient digestibility coefficients were slightly improved with vitamin E plus Se- injected ewes.

The improvements in nutrient digestibility's may be due to positive effects of Se on rumen microorganisms rather than the host ruminants (Wang et al., 2009). Microbial efficiency was lower for the $70 \%$ grain included diet plus supplemental Se, yet, the lower level of grains $(50 \%)$ showed improved digestibility coefficients when supplemental Se was included. Also, Del Razo et al. (2013) found improved microbial and $\mathrm{N}$ efficiency with the $50 \%$ grain diet plus $0.9 \mathrm{mg} \mathrm{Se} / \mathrm{kg} \mathrm{DM}$. Absorption is less in ruminants compared to monogastric animals and this is because selenium gets reduced to insoluble compounds in the rumen Chander (1998).

\section{Nutritive values and Nitrogen balance}

Data of Table (4) showed significant decrements of TDN, DCP, DE and nitrogen balance as the level of Se + Vit. E injection was increased. Corresponding values were significant higher in late pregnancy than early pregnancy. The results of DCP (\%) declared that there weren't any significant differences among the treatments and overall of the two periods. In agreement results were found by, Kumar et al. (2008) who reported non-significant effect of supplemental Se at 0.15 or $0.30 \mathrm{mg} / \mathrm{kg}$ DM on intake of DCP and TDN in sheep. Nicholson et al (1991) found no effect with Se supplementation to all ration of lambs and buffalo calves on nutritive value of ration TDN and DCP.

The overall means of TDN, DCP, DE and nitrogen balance at early period of pregnancy were significantly lower $(\mathrm{p}<0.05)$ than that of the late period of pregnancy. The results of DCP $(\%)$ declared that there weren't any significant differences among the experimental treatments and overall means of the two periods.

Nitrogen balance (NB) of doe goats were $(1.48 \mathrm{~g} / \mathrm{h} / \mathrm{d})$ and $(6.95 \mathrm{~g} / \mathrm{h} / \mathrm{d})$ for the early and late pregnancy periods, respectively. On the other hand, supplementation of both Se plus Vit. E was found to decrease NB at early pregnancy. During late pregnancy, T1 and T2; yet the value was lower $(3.87 \mathrm{~g} / \mathrm{h} / \mathrm{d})$ for T3 may be because of the decrease intake and TNI in total CP with increase Selenium plus vitamin E supplementation (Table 4).

Generally, the superiority in nitrogen retention due to specific ration is affected by several factors such as increasing presence of fermentable energy and possible production of microbial protein synthesis (Hagemeister et al., 1981). Tekchandani and Arom (1978), Khirwar and Arora (1976) and Hansard (1983) noticed that animals fed on high Se diets were in negative state of $\mathrm{N}$ balance and the digestibility of CP and other nutrients were also lower in high-Se groups. It is possible that microbial protein synthesis might have been reduced due to high Se intake. Bakshi et al. (1986) observed significantly higher 
excretion of $\mathrm{N}$ through faces and urine in male buffaloes given high-Se urea treated straw (2.14 ppm Se) as compared to those given low-Se urea treated wheat straw $(0.21 \mathrm{ppm} \mathrm{Se})$. Oldham et at. (1977) reported that there are several factors which can affect protein/nitrogen utilization in ruminants including level, source and degradability of dietary nitrogen, level and type of carbohydrates which match the protein synthetic ability of rumen microbes. Nitrogen balance gives an idea regarding the extent of utilization of dietary nitrogen and finally the amount lost or retained in the body. It is well known that tissue needs for nitrogen of a ruminant animal are met by the microbial protein synthesized in the rumen and the degraded protein that escapes from microbial breakdown further gets digested and absorbed from small intestine. Fecal excretion was comparable in animals given Selene-methionine or sodium selenite but urinary excretion was reduced in animals given Selene-methionine (Ehlig et al., 1967). Fecal excretion is generally greater than urinary excretion in ruminants and exhalation a major route of Se excretion only when toxic concentrations are consumed Chander (1998).

\title{
Body weight of goats
}

Final body weight and total body weight gain are shown in Table (5). Injection of Se plus vitamin E did not have any significant effects on live body weight at 90 days, before and after kidding. The highest final live body weight was recorded for injection $0.125 \mathrm{mg}$ Se plus $1.71 \mathrm{u}$ Vitamin E; T1(23.87) followed by that $0.250 \mathrm{mg}$ Se plus 3.4Iu vitamin E; T2 (21.95) and the lowest one was observed with level 0.310 $\mathrm{mg}$ Se plus 4.2 Vitamin $\mathrm{E}$; $\mathrm{T} 3(20.17 \mathrm{Kg})$. In general, final live body weight was increased with decreasing level of Se plus vitamin E. Also, treatment increased weight gain during pregnancy period in Baladi doe goats after parturition in T2 $(2.40 \mathrm{Kg})$, T1 $(2.33 \mathrm{Kg})$, control $(1.80 \mathrm{Kg})$ compared with T3 $(0.917 \mathrm{Kg})$.

These results are in agreement with those reported by Tufarelli and Laudadio (2011) who found nonsignificant differences $(\mathrm{P}<0.05)$ in body weight gain among groups of dairy Jonica goats fed rations containing sodium selenite as the Se supplement in concentrate $(0.20 \mathrm{mg} / \mathrm{head}$ per day of Na-selenite and $20 \mathrm{mg} /$ day per head of Vit. E). On the contrary, Yue et al. (2009) reported that dietary supplemental Se improved significantly the average gain and the final body weight and average daily gain.

\section{Body weight of kids}

Results of Table (6) clearly indicated that Se+ vit E injection significantly decreased birth weight, 60 days and weaning weights and daily gain of kids compared with control. These results are in agreement with those obtained by Gunter et al. (2003) who mentioned that in pregnant cows, Se supplementation had no effect on body weight; birth weight; total body weight gain, and average daily gain (ADG) of calves. Moreover, Vinu et al (2012) found that supplemented Se- yeast at rate of $0.3 \mathrm{ppm}$ to calves diets did not reveal any significant difference on daily body weight gain as compared with control.

However, Ibrahim (2016) found that maternal Se supplementation improved body gain of their lambs. The beneficial effects of supplemental Se on animal performance was reported to improve birth weight of lambs (Ali et al., 2004) and average body weight for new born lambs (Hefnawy et al., 2014). Gabryszuk and Klewiec (2002). Supplementation of Se $(0.15 \mathrm{mg} \mathrm{Se} / \mathrm{kg}$ of diet) through sodium selenite increased average daily gain improving the growth rate (Kumar et al., 2009). In consistence, Se supplementation increased cow BW, and calf birth, weaning, and post weaning weights, or weight per day of age in early lactation (Sprinkle et al., 2006).

\section{CONCLUSION}

Selenium concentrations change considerably during pregnancy depending on the level of Se injected. The results of the current study revealed that lower level $(0.125 \mathrm{mg}$ Se plus $1.7 \mathrm{IU}$ Vit. E/ $\mathrm{kg} / \mathrm{kg} \mathrm{BW})$ injection during early and late gestation periods improved nutrients digestibility, nutritive values, nitrogen utilization

\section{REFERENCES}

\author{
A.O.A.C. (1997). Official Methods of Analysis. $16^{\text {th }}$ Ed. Assoc. Office. Anal. Chem., Arlington, VA.
}


Ali, A., D.G. Morrical, M.P. Hoffman and M.F. Al-Essa (2004). Evaluation of vitamin E and selenium supplementation in late gestation on lamb survival and pre- weaning growth. The professional Animal Sciences, (20): 506-511.

Bakshi, M.P.S., P.N. Langar, R.P. Rana and J.C. Kalyal (1986). Selenosis in buffaloes fed rice straw. World Rei'. Anim. Prod, 22:57-62.

Brown, K.M. and J.R. Arthur (2001). Selenium, selenoproteins and human health: a review. Public Health Nutrition, 4(2B):593-599.

Ceballos, A., J. Sanchez, H. Stryhn, J.B. Montgomery, H.W. Barkema and J.J. Wichtel (2009): Metaanalysis of the effect of oral selenium supplementation on milk selenium concentration in cattle. Journal of Dairy Science, 92 (1):324-342.

Chander, E.R.D. (1998). Selenium metabolism in the rumen its absorption and urinary excretion in cattle and buffaloes, M.Sc. thesis, (Animal Nutrition). (Deemed University) (I.C.A.R.) Karnal-132 001 (HARYANA), INDIA

Chris F., R. Hostetler, C. Kin and M.A. Mirandl (2003). The role of essential trace elements in embryonic and fetal development in livestock volume 166, Issue 2, 125-139.

Del Razo-Rodriguez, O.E., J.E. Ramirez- Bribiesca, R. Lopez-Are 1lano, A.L. Revilla-Vazquez, S.S. Gonzalez- Munoz, M.A. Cobos-Peralta, L.M. Hernandez -Calva and L.R. McDowell (2013). Effects of dietary level of selenium and grain on digestive metabolism in lambs. Czech J. Anim. Sci., 58(6): 253-261.

Duncan, D.B. (1955). Multiple range and multiple F - tests. Biometrics, 11: 1-42.

Ehlig, C.F., D.E. Ilogue, W.H. Allaway and L. Hamm (1967). Fate of selenium from selenite or selenomethionine with or without vitamin $\mathrm{E}$ in lambs. J. ar. , 92:121.

Gabryszuk, M., and J. Klewiec (2002). Effect of injecting 2- and 3-year-old ewes with selenium and selenium -vitamin E on reproduction and rearing of lambs. Small Rumin. Res., 43: 127-132.

Gunter, S.A. P.A. Beck and J.M., Hillips (2003). Effects of supplementary selenium source on the performance and blood measurements in beef cows and their calves. J. Anim. Sci., 81:856-864.

Gutteridge, J.M.C. and B.C. Halliwell (1994). Free radicals and antioxidants in ageing and disease: fact or Fantasy. In: Antioxidants in nutrition, Health and Disease. Oxford Univ. press. Oxford, pp:111-123.

Hagemeister, H., W. Lipping and W.K. Kaufimann (1981). Microbial protein synthesis and digestion in the high yielding dairy cow. In: Recent Advances in Animal Nutrition. resign, PP.67. Butterworth, London.

Hansard, S.L. (1983). Microelements for ruminant animals. A Review. Nutr. Absfr. Rev.SeriesB, 53:1-24.

Hefnawy, Abd Elghany, Seham Youssef, P. Villalobos Aguilera, C. Valverde Rodríguez and J.L. Tórtora Pérez (2014). The Relationship between Selenium and T3 in Selenium Supplemented and Nonsupplemented Ewes and Their Lambs. Veterinary Medicine International J., Volume 2014, Article ID 105236, 6 pages.

Ibrahim, E.M. (2017). Effect of parenteral supplementation of vitamin E plus selenium on nutrient digestibility, productive performance and some serum biochemical indicators of lambs. Egyptian Journal of sheep \& Goat Sciences, 12(1):59-70.

Ibrahim. E.M. (2016). Productive performance, nutrients digestibility and some serum metabolic indices as affected by dietary supplementation of copper and zinc in Egyptian buffalo calves. J Nutrition and Feeds, 19 (2): 187-197.

Juniper, D.T., R.H. Phipps, D.L. Givens, A.K. Jones, C. Green and G. Bertin (2008). Tolerance of ruminant animals to high dose in -feed administration of a selenium- enriched yeast. J Anim Sci., 86:197-204.

Kassab, A.Y. and A.A. Mohammed (2014). Effect of vitamin E and Selenium on some physiological and reproductive characteristics of Sohagi ewes Egyptian J. Nutrition and Feeds, 17(1): 9-18.

Kearl, L.C. (1982). Nutrient requirement of ruminates in developing countries international feedstuffs Institute Utah Agric. EXP. Station, Utah state Univ. Logan, U.S.A.

Kelleher, J. (1991). Vitamin E and the immune response. Proc. Nutr: Soc., 50: 245-249. 
Khirwar, S.S. and S.P. Arora (1976). Influence of different levels of selenium on protein synthesis in vitro. Milchwissenschaft, 31:275-277.

Kholif, S.M. and A.M. Kholif (2008). Effect of selenium enriched yeast supplementation on the productive.

Kolb, E. and J. Seehawer (1998). The development of the immune system and vitamin levels in the bovine fetus and neonate: a review including the effect of vitamins on the immune system. Tiera. Rztl. Umsch., 53:723-730.

Kumar, N., A.K. Garg, V.K. Chaturvedi and V.P. Varshey (2008). Effect of different levels of selenium supplementation on growth rate, nutrient utilization, blood metabolic profile, and immune response in lambs. Biol Trace Trace Elem. Res. 126 (Suppl: 1): S44-S56.

Kumar, N., A. K. Garg, R.S. Dass, V.K. Chaturvedi, V. Mudgal and V.P. Varshney (2009). Selenium supplementation influences growth performance, antioxidant status and immune response in lambs. Journal of Animal Feed Science and Technology, 153 (1): 77-87.

Marai, I.F.M., A. El-Darawany, E.A. Ismail and M.A.M. Abdel-Hafez (2009). Reproductive and physiological traits of Egyptian Suffolk rams as affected by selenium dietary supplementation and housing heat radiation effects during winter of the sub -tropical environment of Egypt. Arch. Tierzucht., 52(4):402-409.

Mayland, H.F., L.F. James, K.E. Panter, and J.L. Sondergger (1989). Selenium is Seleniferous environments Soil Science society of America and American society of Agronomy, 677: 15.

Mc Dowell, L.R., S.N. Williams and N. Hidiroglou (1996). Vitamin E supplementation for the ruminants. Anim. Feed Sci. Technol., 60: 273-296.

Neeraj, K., A.K. Garg, V. Mudgal, R.S. Dass, V.K. Chaturvedi and V.P. Varshney (2008). Effect of different levels of selenium supplementation on growth rate, nutrient utilization, blood metabolic profile, and immune response in lambs. Biol. Trace. Elem. Res., 126 (suppl: 1): S44-S56.

Nicholson, J., W.G. McQueen and R.S. Bush (1991). Response of growing cattle to supplementation with organically bound or inorganic sources of selenium or yeast cultures. Canadian journal of animal Science, 71(3):803-811.

NRC (1985). Nutrient Requirements of sheep: $6^{\text {th }}$ Revised Edition. National Academy Press, Washington, D.C.

Oldham, J.D., P.J. Bullery, H. Swan and D. Lewis (1977). Interactions between dietary carbohydrates and nitrogen and digestion in sheep. J. Agri. Sci., 89:467.

Ramirez- Bribiesca, J.E., J. Tortora, M. Huerta, I.M. Hernandez, R. Lopez, M.M. Cosby (2005). Effect of Selenium-Vitamin E injection in Selenium-deficient dairy goats and Kids on Mexican plateau. Arqivo Brasileiro De Medicina Vetrinaria E Zootecnia, 57(1): 77-84.

Rikans, L.E., D.R. Moore and C.D. Snowden (1991). Sex-dependent differences in the effects of aging on antioxidant defense mec-hanisms of rat liver. Biochimica et Biophysica. Acta, 1074: 195-200.

Salama, R., M.A. Boraei, M.A.I. El-Sysy and M. Fouda (2015). Effect of Vitamin E Supplementation on the productive performance of Rahmani sheep. Egyptian J. Nutrition and Feeds, 18 (2) Special Issue: 65-75.

SAS (2004). SAS/STAT User's Guide: version. 9.1.3 SAS Institute Inc., Cary, NC.

Serra, A.B., K. Nakamura, T. Matsui, T. Harumoto and T. Fujihara (1994). Inorganic selenium for sheep. II. Its influence on rumen bacterial yield, volatile fatty acid production and total tract digestion of timothy hay. Asian Ausl. J. Anim. Sci., 7:91-96.

Sheffy, B.E. and R.D. Schulty (1979). Influence of vitamin E and Se on immune response mechanism. Fed proc., 38:2139.

Shi, L., W. Xun, W. Yue, C. Zhang, Y. Ren, L. Shi and F. Lei (2011). Effect of sodium selenite, Se- yeast and Nano- elemental Selenium on growth performance, Se concentration and antioxidant status in growing male goats. Small Ruminant Research, 96(1):49-52.

Sprinkle, J.E., S.P. Cuneo, H.M. Frederick, R.M. Enns, D.W. Schafer, G.E. Carstens, S.B. Daugherty, T.H. Noon, B.M. Rickert and C. Reggiardo (2006). Effects of a long- acting, trace mineral, 
reticulorumen bolus on range cow productivity and trace mineral profiles. J.Anim. Sci., 84(6): 14391453.

Tekchandani. N. and S.P. Arora (1978). Incorporation of 1SSe-L-selenomethionine in rabbit tissue proteins and rumen microbial proteins in the cow. Iudiou. J. Dairy Sci., 31:345-349.

Tufarelli, V. and V. Laudadio (2011). Dietary supplementation with selenium and vitamin E improves milk yield, composition and rheological properties of dairy Jonica goats. J Dairy Res., 78(2):144-148.

Vinu, M.N., P. Gangadevi, A.D. Mercy, K.S. Anil and K. Shyama (2012). Effect of dietary supplementation of organic selenium on growth performance and nutrient utilization in cross-bred calves. J. Vet. Anim. Sc., 43:36-40.

Wang, C., Q. Liu, W.Z. Yang, Q.D. Dong, X.M. Yang, D.C He and P. Zhang (2009). Effects of selenium yeast rumen fermentation, lactation performance and feed digestibilities in lactating dairy cows. Livestock Science, 126:239-244.

Yue, W., C. Zhang, L. Shi, Y. Ren, Y. Jiang and D.O. Kleemann (2009). Effect of supplemental selenomethionine on growth performance and serum antioxidant status in Taihang black goats. AsianAust. J. Anim. Sci., 22:365-370.

Zohreh, T., K. Saeid, M. Hossein and M. Ali (2018). Supplementation of different selenium sources during early lactation of native goats and their effects on nutrient digestibility, nitrogen and energy status, Journal of Applied Animal Research, 46(1): 64-68.

تأثير الحقن بالسلينيوم وفيتامين هـ على معاملات الهضم والقيمة الغذائية لإناث الماعز البلدي في جنوب سيناء

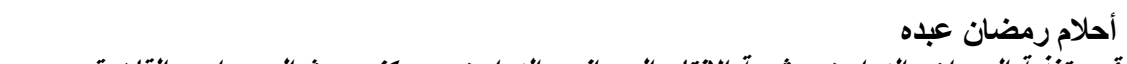

الهدف من البحث: تحديد الجر عة المناسبة من السيلينيوم بالإضافة إلى فيتامين هـ على أداء الإنتاجي للماعز خلال فترني الحمل و الحليب.

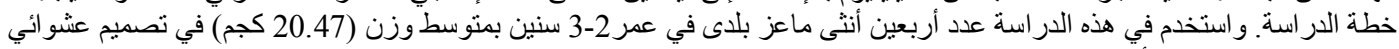

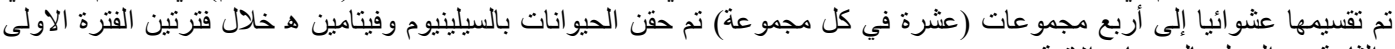
و الثانية من الحمل بالجر عات الاتية:

$$
\text { المجموعة: (كنترول) }
$$

$$
\begin{aligned}
& \text { المعاملة الأولى: } 0.125 \text { ملليجر ام سيلينيوم + 1.7وحدة دولية فيتامين هـ لكل كجم من وزن الجسم } \\
& \text { المعاملة الثانية: } 0.250 \text { ملليجر ام سيلينيوم + } 3.4 \text { وحدة دولية فيتامين هـ لكل كجم من وزن الجسم }
\end{aligned}
$$

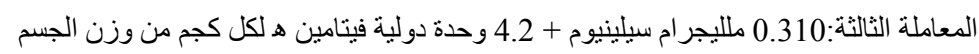$$
\text { و أجريت تجارب هضم بعد كل حقنة ونم تقدير وزن الجسم للأمهات و المو اليد وتم تقدير قياسات الدم و الاملاح و اللبن }
$$$$
\text { أهم النتائج المتحصل عليها: }
$$

1. أوضحت النتائج أن الحقن بالسيلينيوم وفيتامين هـ عدم وجود اختلافات معنوية في المادة الجافة المأكولة والبروتين الخام المأكول خلال فترتي الحمل

2. أظهرت مجموعه الكنترول اعلي قيمة في معامل هضم البروتين عن المجموعات المعاملة وزاد معامل هضم الدهن مع زيادة

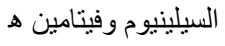

3. حدث زيادة في مجموع المركبات الكلية المهضومة في الفترة الأخيرة من الحمل وانخفاض ميزان النيتروجين في أول وأخر الحمل

4. جدول 6 يوضح أن اعلى متوسط وزن فطام كان للمجموعة T2 (جرعة متوسطة) يليها الكنترول ثم T1 وان أعلى زيادة وزنية كان T2 T2 جيليه 
Egyptian J. Nutrition and Feeds (2021)

Table (1): Chemical composition of concentrate diet and Berseem hay (on DM basis, \%).

\begin{tabular}{|c|c|c|c|c|c|c|c|c|c|}
\hline \multirow[t]{2}{*}{ Item } & \multicolumn{9}{|c|}{ Chemical composition } \\
\hline & DM & OM & $\mathrm{CP}$ & $\mathrm{CF}$ & $\mathrm{EE}$ & NFE & Ash & Se mg/kg DM & $\mathrm{DE}^{* *}$ \\
\hline CFM* $^{*}$ & 92.40 & 93.76 & 16.87 & 7.47 & 2.80 & 66.62 & 6.24 & 0.076 & 3290 \\
\hline Berseem hay & 91.33 & 85.75 & 15.16 & 30.94 & 2.11 & 37.54 & 14.25 & 0.058 & 2100 \\
\hline
\end{tabular}

${ }^{*}$ CFM concentrates feed mixture, DE** Digestible energy (DE, M cal///kg DM)

Table (2): Effect of treatment on feed intake and body weight of Baladi doe goats during pregnancy periods.

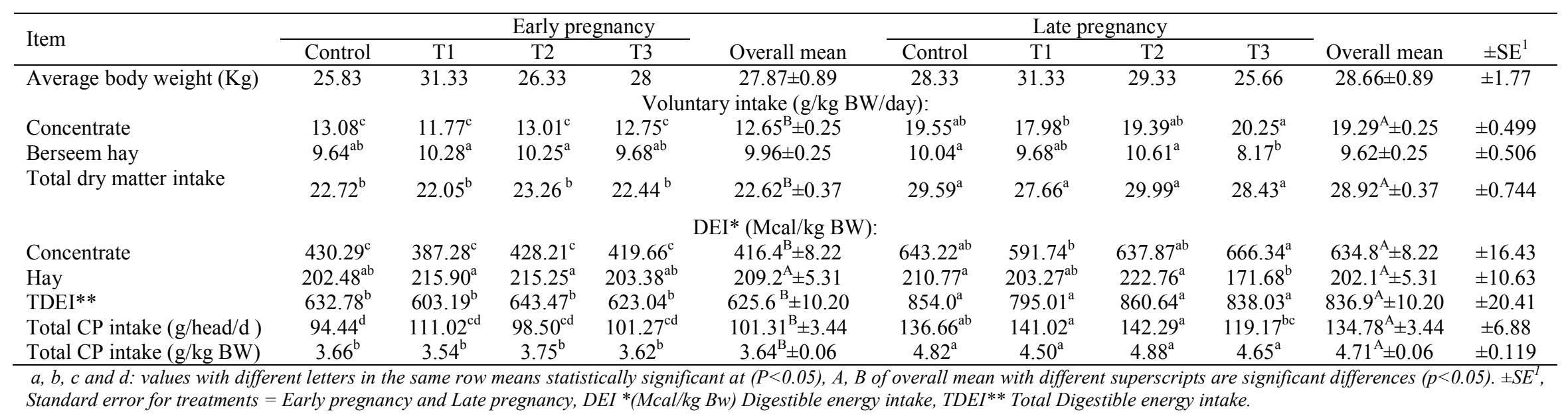


Table (3): Effect of treatment on nutrients digestibility of Baladi doe goats during early and late pregnancy period.

\begin{tabular}{|c|c|c|c|c|c|c|c|c|c|c|c|}
\hline \multirow{2}{*}{ Item } & \multicolumn{4}{|c|}{ Early pregnancy } & \multirow[b]{2}{*}{ Overall mean } & \multicolumn{4}{|c|}{ Late pregnancy } & \multirow[b]{2}{*}{ Overall mean } & \multirow[b]{2}{*}{$\pm \mathrm{SE}^{1}$} \\
\hline & Control & T1 & $\mathrm{T} 2$ & T3 & & Control & T1 & $\mathrm{T} 2$ & T3 & & \\
\hline $\mathrm{DM}$ & $74.48^{\mathrm{ab}}$ & $71.59^{\mathrm{abc}}$ & $68.87^{\mathrm{c}}$ & $67.22^{\mathrm{c}}$ & $70.54^{\mathrm{B}} \pm 0.71$ & $76.13^{\mathrm{a}}$ & $75.60^{a}$ & $73.46^{\mathrm{ab}}$ & $70.37^{\mathrm{bc}}$ & $73.89^{\mathrm{A}} \pm 0.71$ & \pm 1.41 \\
\hline $\mathrm{OM}$ & $76.53^{\mathrm{ab}}$ & $73.22^{\mathrm{abcd}}$ & $70.68^{\mathrm{dc}}$ & $69.44^{\mathrm{d}}$ & $72.46^{\mathrm{B}} \pm 0.68$ & $77.32^{\mathrm{a}}$ & $76.94^{\mathrm{a}}$ & $74.75^{\mathrm{abc}}$ & $72.16^{\mathrm{bcd}}$ & $75.29^{\mathrm{A}} \pm 0.68$ & \pm 1.36 \\
\hline $\mathrm{CP}$ & $76.74^{\mathrm{a}}$ & $72.18^{\mathrm{bc}}$ & $72.07^{\mathrm{bc}}$ & $70.12^{\mathrm{c}}$ & $72.78 \pm 0.59$ & $74.96^{\mathrm{ab}}$ & $75.60^{\mathrm{ab}}$ & $72.99 \mathrm{a}^{\mathrm{bc}}$ & $72.03^{\mathrm{bc}}$ & $73.89 \pm 0.59$ & \pm 1.17 \\
\hline $\mathrm{EE}$ & 76.72 & 77.61 & 79.86 & 77.29 & $77.87^{\mathrm{A}} \pm 0.94$ & 72.54 & 72.14 & 68.30 & 73.21 & $71.54^{\mathrm{B}} \pm 0.94$ & \pm 7.87 \\
\hline $\mathrm{CF}$ & $60.38^{\mathrm{a}}$ & $58.79^{\mathrm{a}}$ & $49.53^{c}$ & $52.16^{\mathrm{bc}}$ & $55.92 \pm 0.92$ & $58.59^{\mathrm{a}}$ & $59.28^{\mathrm{a}}$ & 56. $77^{\mathrm{ab}}$ & $48.36^{c}$ & $55.75 \pm 0.92$ & \pm 1.83 \\
\hline NFE & $81.61^{\mathrm{abc}}$ & $78.33^{\mathrm{bcd}}$ & $76.83^{\mathrm{de}}$ & $75.21^{\mathrm{e}}$ & $77.99^{\mathrm{B}} \pm 0.66$ & $83.29^{\mathrm{a}}$ & $82.46^{\mathrm{ab}}$ & $80.59^{\mathrm{abc}}$ & $77.97^{\text {cde }}$ & $81.08^{\mathrm{A}} \pm 0.66$ & \pm 1.33 \\
\hline
\end{tabular}

$a, b, c$ and $d$ : values with different letters in the same row means statistically significant at $(P<0.05)$, A, B of overall mean with different superscripts are significant differences ( $p<0.05)$. \pm SE Standard error for treatments = Early pregnancy and Late pregnancy

Table (4): Effect of treatment on nutritive values and nitrogen utilization of Baladi doe goats during early and late pregnancy periods.

\begin{tabular}{|c|c|c|c|c|c|c|c|c|c|c|c|}
\hline \multirow[b]{2}{*}{ Item } & \multicolumn{4}{|c|}{ Early pregnancy } & \multirow[b]{2}{*}{$\begin{array}{c}\text { Overall } \\
\text { mean }\end{array}$} & \multicolumn{4}{|c|}{ Late pregnancy } & \multirow[b]{2}{*}{$\begin{array}{c}\text { Overall } \\
\text { mean }\end{array}$} & \multirow[b]{2}{*}{$\pm \mathrm{SE}^{1}$} \\
\hline & Control & $\mathrm{T} 1$ & $\mathrm{~T} 2$ & $\mathrm{~T} 3$ & & Control & $\mathrm{T} 1$ & $\mathrm{~T} 2$ & $\mathrm{~T} 3$ & & \\
\hline Nutritive values: & & & & & & & & & & & \\
\hline TDN \%* & $71.57^{\mathrm{ab}}$ & $68.32^{\mathrm{bc}}$ & $66.26^{\mathrm{c}}$ & $65.52^{\mathrm{c}}$ & $67.92^{\mathrm{B}} \pm 0.59$ & $72.72^{\mathrm{a}}$ & $72.29^{\mathrm{a}}$ & $70.14^{\mathrm{ab}}$ & $68.37^{\mathrm{bc}}$ & $70.88^{\mathrm{A}} \pm 0.59$ & \pm 1.19 \\
\hline DCP $\% * *$ & 12.39 & 11.16 & 11.61 & 11.19 & $11.59 \pm 0.15$ & 12.21 & 12.30 & 11.87 & 11.80 & $12.04 \pm 0.15$ & \pm 0.307 \\
\hline $\mathrm{DE}(\mathrm{Mcal} / \mathrm{kg} \mathrm{DM}) * * *$ & $3.15^{\mathrm{ab}}$ & $3.01^{\mathrm{bc}}$ & $2.92^{\mathrm{c}}$ & $2.89^{\mathrm{c}}$ & $2.99^{\mathrm{B}} \pm 0.03$ & $3.21^{\mathrm{a}}$ & $3.19^{\mathrm{a}}$ & $3.09^{\mathrm{ab}}$ & $3.01^{\mathrm{bc}}$ & $3.12^{\mathrm{A}} \pm 0.03$ & \pm 0.052 \\
\hline Nitrogen utilization $\mathrm{g} / \mathrm{h} / \mathrm{d}$ : & & & & & & & & & & & \\
\hline Nitrogen intake $\mathrm{g} / \mathrm{h} / \mathrm{d}$ & 15.11 & 17.76 & 15.76 & 16.20 & $16.21^{\mathrm{B}} \pm 0.55$ & 21.86 & 22.56 & 22.76 & 19.06 & $21.56^{\mathrm{A}} \pm 0.55$ & \pm 1.10 \\
\hline Execration nitrogen $\mathrm{g} / \mathrm{h} / \mathrm{d}^{2}$ & 12.95 & 16.23 & 14.51 & 15.19 & $14.72 \pm 0.45$ & 13.47 & 14.27 & 15.49 & 15.19 & $14.61 \pm 0.45$ & \pm 0.899 \\
\hline Nitrogen balance $\mathrm{g} / \mathrm{h} / \mathrm{d}$ & $2.16^{\mathrm{c}}$ & $1.53^{\mathrm{c}}$ & $1.24^{\mathrm{c}}$ & $1.01^{\mathrm{c}}$ & $1.48^{\mathrm{B}} \pm 0.18$ & $8.38^{\mathrm{a}}$ & $8.29^{\mathrm{a}}$ & $7.27^{\mathrm{a}}$ & $3.87^{\mathrm{b}}$ & $6.95^{\mathrm{A}} \pm 0.18$ & \pm 0.362 \\
\hline $\begin{array}{l}\mathrm{N} \text { - balance as \% of nitrogen } \\
\text { intake }\end{array}$ & $14.23^{\mathrm{d}}$ & $8.58^{\mathrm{e}}$ & $7.89^{\mathrm{e}}$ & $6.20^{\mathrm{e}}$ & $9.23^{\mathrm{B}} \pm 0.74$ & $38.53^{\mathrm{a}}$ & $36.7^{\mathrm{a}}$ & $31.9^{\mathrm{b}}$ & $19.83^{\mathrm{c}}$ & $31.80^{\mathrm{A}} \pm 0.74$ & \pm 1.48 \\
\hline
\end{tabular}

$a, b, c$ and $d$ : values with different letters in the same row means statistically significant at $(P<0.05), A, B$ of overall mean with different superscripts are significant differences ( $p<0.05)$. TDN,

*Total digestible nutrients, DCP, **Digestible crude protein, DE***Digestible energy (M cal/kg DM) $=0.04409 * T D N \%$ was calculated according to N.R.C (1988), \pm SE ${ }^{l}$, Standard error $=$

Early pregnancy and Late pregnancy, Execration nitrogen $g / h / d^{2}=N$ faces $+N$ urine 
Egyptian J. Nutrition and Feeds (2021)

Table (5): Effect of treatment on body weight changes of Baladi doe goats during gestation.

\begin{tabular}{lcccc}
\hline Item & Control & $\mathrm{T} 1$ & $\mathrm{~T} 2$ & $\mathrm{~T} 3$ \\
\hline Initial body weight(kg) & $20.30 \pm 1.91$ & $21.92 \pm 1.74$ & $19.90 \pm 1.91$ & $19.75 \pm 1.74$ \\
Body weight at 90 days (kg) & $24.71 \pm 1.86$ & $25.96 \pm 1.70$ & $23.70 \pm 1.86$ & $22.56 \pm 1.70$ \\
Body weight before kidding & $28.50 \pm 1.93$ & $30.52 \pm 1.76$ & $28.96 \pm 1.93$ & $26.21 \pm 1.76$ \\
Body weight after kidding & $21.10 \pm 1.67$ & $24.25 \pm 1.52$ & $22.30 \pm 1.67$ & $20.66 \pm 1.52$ \\
Body weight loss, just after kidding( kg) & $6.40 \pm 0.827$ & $6.27 \pm 0.755$ & $6.66 \pm 0.827$ & $5.55 \pm 0.755$ \\
\%of body weight loss, & $22.25 \pm 2.28$ & $20.93 \pm 2.08$ & $23.12 \pm 2.28$ & $20.86 \pm 2.08$ \\
Final live body weight (kg) & $21.74 \pm 1.66$ & $23.87 \pm 1.52$ & $21.95 \pm 1.66$ & $20.17 \pm 1.52$ \\
body weight gain( g/day) & $1.80 \pm 0.767$ & $2.33 \pm 0.700$ & $2.40 \pm 0.767$ & $0.917 \pm 0.700$ \\
Total body weight gain (g/day) & $1.44 \pm 0.762$ & $1.96 \pm 0.695$ & $2.05 \pm 0.762$ & $0.421 \pm 0.695$ \\
\hline
\end{tabular}

$a, b, c$ and $d$ : values with different letters in the same row means statistically significant at $(P<0.05)$.

Table (6): Effect of treatment on birth weight and daily gain of kids.

\begin{tabular}{lcccc}
\hline Item & Control & $\mathrm{T} 1$ & $\mathrm{~T} 2$ & $\mathrm{~T} 3$ \\
\hline Number of kids born alive & 7 & 9 & 8 & 8 \\
Birth weight $(\mathrm{kg})$ & $2.55^{\mathrm{a}} \pm 0.206$ & $2.14^{\mathrm{ab}} \pm 0.168$ & $1.98^{\mathrm{ab}} \pm 0.184$ & $1.86^{\mathrm{b}} \pm 0.148$ \\
Body weight of kid at 60 days, $\mathrm{kg}$ & $8.50 \pm 0.458$ & $7.83 \pm 0.374$ & $7.70 \pm 0.409$ & $7.30 \pm 0.409$ \\
No. of weaned kids & 5 & 7 & 6 & 6 \\
Average weaning weight $(\mathrm{kg})$ & $13.25 \pm 0.709$ & $13.0 \pm 0.579$ & $13.30 \pm 0.635$ & $12.10 \pm 0.635$ \\
Total body weight gain $(\mathrm{kg})$ & $10.70 \pm 0.659$ & $10.86 \pm 0.538$ & $11.32 \pm 0.589$ & $10.24 \pm 0.589$ \\
Total daily gain gm/day & $89.16 \pm 5.49$ & $90.48 \pm 4.48$ & $91.25 \pm 4.91$ & $85.28 \pm 4.91$ \\
\hline$a, b, c$ and $d:$ values with different letters in the same row means statistically significant at $(P<0.05)$,
\end{tabular}

